ОСОБЛИВОСТІ ЕЛЕМЕНТІВ САМОСВІДОМОСТІ ДІТЕЙ СТАРШОГО ДОШКІЛЬНОГО ВІКУ ІЗ СИСТЕМНИМИ ПОРУШЕННЯМИ МОВЛЕННЯ

\title{
FEATURES OF ELEMENTS OF SELF-CONSCIOUSNESS OF CHILDREN OF SENIOR PRESCHOOL AGE WITH SYSTEMIC SPEECH DISORDERS
}

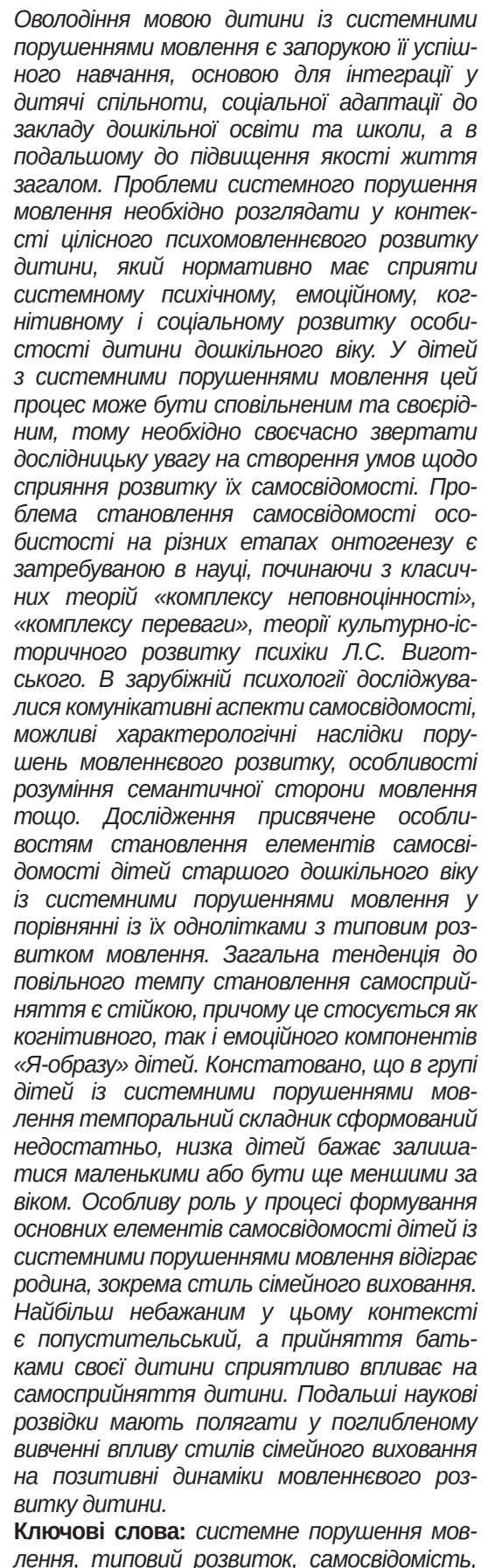

часова перспектива, самосприйняття, сімейне виховання, стиль виховання.

Mastering the language of a child with systemic speech disorders is the key to its successful learning, the basis for integration into children's communities, social adaptation to preschool and school, and further to improve the quality of life in general. Problems of systemic speech disorders should be considered in the contex of holistic psycholinguistic development of the child, which should normatively contribute to the systemic mental, emotional, cognitive and social development of the personality of the preschool child. In children with systemic speech disorders, this process can be slow and peculiar, so it is necessary to pay timely research attention to creating conditions to promote the development of their self-awareness. The problem of formation of self-consciousness of the individual at different stages of ontogenesis is in demand in science, starting with the classical theories of "inferiority complex", "advantage complex", the theory of cultural and historical development of the psyche LS Vygotsky. In foreign psychology, the communicative aspects of self-awareness, possible characterological consequences of speech development disorders, features of understanding the semantic side of speech, etc. were studied. The study is devoted to the peculiarities of the formation of elements of self-awareness of older preschool children with systemic speech disorders in comparison with their peers with the normative development of speech. The general tendency to a slow pace of self-perception is stable, and this applies to both cognitive and emotional components of the "self-image" of children. It was stated that in the group of children with systemic speech disorders the temporal component is insufficiently formed, a number of children want to stay small or be even younger. A special role in the formation of the basic elements of self-consciousness of children with systemic speech disorders is played by the family, in particular the style of family upbringing. The most undesirable in this context is permissive. And the adoption of the parents of their child has a beneficial effect on the child's self-perception. Further scientific research should consist in an in-depth study of the influence of family upbringing styles on the positive dynamics of a child's speech development.

Key words: systemic speech disorders, normative development, self-awareness, time perspective, self-perception, family upbringing, upbringing style.

педагогічний університет

імені К.Д. Ушинського

Постановка проблеми. Оволодіння мовою $є$ не тільки запорукою успішного навчання дитини із системними порушеннями мовлення, а й основою для ії̈ успішної інтеграції у дитячі спільноти, соціальної адаптації до закладу дошкільної освіти та школи та в подальшому до підвищення якості життя загалом. Якість і кількість контактів дитини з оточуючим світом визначає їі соціальний та емоційний розвиток, формує здатність до когнітивної діяльності. Саме завдяки системі спілкування і соціалізації розвиваються сенсомоторні, лінгвістичні функції дитини, які забезпечують подальший розвиток осо- 
бистості. Проблеми системного порушення мовлення можна розглядати ширше - як проблеми психомовленнєвого розвитку дитини, які дуже негативно позначаються на цілісному психічному, емоційному, когнітивному і соціальному розвитку особистості. Чим раніше виявлені порушення мовлення і чим точніше визначені його причини, тим більш сприятливі перспективи особистісного становлення, тим вірогідніше позитивне ставлення дитини до себе та до оточуючих. У дітей з системними порушеннями мовлення цей процес може бути сповільненим та своєрідним, тому необхідно своєчасно звертати дослідницьку увагу на створення умов щодо сприяння розвитку їх самосвідомості.

Аналіз останніх досліджень і публікацій. Проблема становлення самосвідомості особистості на різних етапах її онтогенезу завжди приваблювала науковців, починаючи 3 уже класичних теорій «комплексу неповноцінності» та «комплексу переваги» А. Адлера, «Я-образу» К. Хорні та теорії культурно-історичного розвитку психіки Л.С. Виготського. В зарубіжній психології ці аспекти досліджувалися C. Baltaxe \& J. Simmons [10] (комунікативні аспекти), J. Beitchman, J. Hood \& A. Inglis [11] (можливі характерологічні наслідки порушень мовленнєвого розвитку), Z. Tarkowski [12] (особливості розуміння семантичної сторони мовлення) та інші.

У вітчизняному науковому просторі проблема розвитку самосвідомості широко представлена в дослідженнях Є.І. Головахи [4], 3.О. Кіреєвої [5], які розглядають ії через темпоральні аспекти; Ф.Є. Василюка [3] - через систему переживань особистості та інші.

Означені теорії самосвідомості переважно присвячені вивченню психіки особистості у періоді зрілості, але практично не торкаються самосвідомості дитини, яка розвивається нормативно, або має особливі освітні потреби. До нечисленних досліджень у цьому напряму можна віднести наукові доробки В.У. Кузьменко, присвячені вивченню індивідуальності дітей дошкільного віку [7], Г.М. Бреслав - щодо ризиків їх емоційної децентрації [2], Н.М. Могільової - щодо комунікативного компоненту самосвідомості дітей молодшого шкільного віку із загальним недорозвиненням мовлення [9], І.В. Мартиненко, присвячені вивченню комунікативної діяльності старших дошкільників із системними порушеннями мовлення з позицій особистісно-орієнтованого, діяльнісного та системного теоретико-методологічних підходів [8].

Постановка завдання. Основною метою нашого дослідження було виявлення таких важливих компонентів самосвідомості дітей старшого дошкільного віку із такими системними порушеннями мовлення, як: здатність до самосприйняття, особливості Я-образу, становлення психологічного часу та їх вербальні звіти в процесі роботи.

Об'єкт дослідження: самосвідомість дітей із системними порушеннями мовлення.

Предмет дослідження: психологічні особливості самосвідомості дітей старшого дошкільного віку із системними порушеннями мовлення.

У дослідженні взяли участь діти з типовим розвитком мовлення (30) та із його системними порушеннями (30). Усього в роботі взяли участь 60 дітей старшого дошкільного віку.

Для досягнення мети використовувалися методи: спостереження, гра, констатувальний експеримент.

Виклад основного матеріалу дослідження. В процесі констатувального експерименту за допомогою методики «Фізичне Я» досліджувалося уміння дітей описувати свою зовнішність під час її безпосереднього сприйняття, знання про функціональне призначення основних частин тіла, наявність первинної ідентифікації зі статтю, можливість висловити вербально емоційне ставлення до своєї зовнішності; за допомогою методики «Фотозагадки» досліджувалися встановлення наявності у дитини можливості усвідомлення себе, часового зсуву у психіці, розуміння вікової послідовності, ставлення до дорослішання. За допомогою методу анкетування батьків досліджувався домінуючий тип сімейного вихованн (надвимогливий, протирічний (непослідовний), попустительський, принимаючий).

Порівняння результатів дітей старшого дошкільного віку в обох групах показали наступні результати, відображені у таблиці 1.

У старшому дошкільному віці діти з типовим розвитком мовлення не відчувають жодних складнощів щодо перерахування будь-яких частин свого тіла, дають повні та розгорнуті відповіді про функціональне призначення цих частин тіла. Наприклад, Оля А., 5 років, відповідаючи на питання, каже: «Руки існують, щоб людина могла усе робити: малювати, грати, а ноги для того існують, щоб ходити, бігати, пригати, голова для того, щоб думати». Але необхідно відмітити, що надати опис себе на рівні фізичного вигляду без допомоги дорослого не змогла жодна дитина з типовим розвитком мовлення, що підтверджує факт складності цього завдання для дітей дошкільного віку. Емоційне ставлення до власного фізичного вигляду у дітей було позитивним, вони надавали собі добру оцінку, але переважно хвалили свій одяг. Лише окремі діти називали себе «красивими».

У дітей із системними порушеннями мовлення були отримані інші результати. Більшість з них (74\%), розглядаючи себе у дзеркалі, називали лише основні частини обличчя, 
Особливості показників уявлення про “фізичне Я" дітей старшого дошкільного віку при типовому розвитку мовлення та його системних порушеннях

\begin{tabular}{|l|c|c|c|}
\hline \multicolumn{1}{|c|}{$\begin{array}{c}\text { Група дітей } \\
\text { (кількість) }\end{array}$} & $\begin{array}{c}\text { Диференційованість } \\
\text { самосприйняття }\end{array}$ & $\begin{array}{c}\text { Знання функцій } \\
\text { частин тіла }\end{array}$ & $\begin{array}{c}\text { Емоційне ставлення } \\
\text { до себе }\end{array}$ \\
\hline $\begin{array}{l}\text { Типовий розвиток } \\
\text { мовлення (30 дітей) }\end{array}$ & $4,00 \pm 0,00$ & $4,97 \pm 0,05$ & $2,88 \pm 0,04$ \\
\hline $\begin{array}{l}\text { Системні порушення } \\
\text { мовлення (30 дітей) }\end{array}$ & $2,41 \pm 0,18$ & $3,16 \pm 0,17$ & $0,95 \pm 0,1$ \\
\hline
\end{tabular}

Примітка: $p<0,001$

щодо функціонального призначення інших частин тіла відповідали неповно та одноманітно: наприклад, Сергійко Д., 5, 2 роки, надав наступні відповіді: «Руки - брати, ноги ходити. Голова...». Відмінності між обома групами мали високий рівень достовірності.

Із таблиці 1 ми бачимо, що загальна тенденція до повільного темпу становлення самосприйняття є стійкою, причому це стосується як когнітивного, так і емоційного компонентів «Я-образу» дітей.

За допомогою методики «Фотозагадки» ми досліджували здатність дітей обох груп до порівняння себе з однолітками, що лежить в основі становлення ціннісного ставлення до себе та інших. Під час виконання завдання дитині було необхідно порівняти себе та однолітка. В групі дітей з типовим розвитком мовлення $70 \%$ виконали це завдання відносно самостійно, за допомогою додаткових питань психолога, а в групі із системними порушеннями мовлення - лише 9\% $(p<0,001)$. Але необхідно відмітити, що в обох групах знову у порівнянні зберігалася тенденція орієнтуватися лише на зовнішні ознаки. Труднощі порівняння в групі дітей із системними порушеннями мовлення були стійкі: описати фотографію, а тим більш порівняти на ній себе із однолітком жодна дитина не змогла.

Тобто ми можемо зафіксувати, що на розвиток уявлення про себе та усний звіт про виконання завдань суттєвий вплив створюють складнощі когнітивного та мовленнєвого розвитку.

Оскільки, як було нами відмічено вище, вітчизняна психологічна школа суттєво орієнтується на темпоральні аспекти розвитку самосвідомості в онтогенезі, ми припустили, що можливість дитини усвідомлювати себе у часовій перспективі, розділяти аспекти психологічного минулого та майбутнього не тільки $€$ важливим елементом формування самосвідомості, але й додатковим елементом мовленнєвого розвитку.

Зміст завдання полягав у тому, що дитині було необхідно порівняти своє сучасне фото 3 фотографією, зробленою у більш молодшому віці (додаткова інструкція методики «Фотозагадка»). Виявилося, що для більшості дітей обох груп зміст завдання був складний, відмічалися лише несуттєві ознаки.

Діти старшого дошкільного віку з типовим розвитком мовлення відносно точно визначають свій вік на фотографії з минулого (51\%), в групі із системними порушеннями мовлення ці показники менші (42\%). Це може свідчити про те, що категорія психологічного минулого вже присутня в самосвідомості дітей старшого дошкільного віку обох груп та $€$ важливим складником їх цілісного образу «я». В старшому дошкільному віці у дітей з типовим мовленнєвим розвитком проявляється уміння детально розповідати про себе маленького. В нашому дослідженні це уміння було зафіксовано у 38,47\% дітей: «Коли я була маленька, то часто плакала, хотіла до мами, зараз я виросла та люблю гратися сама» (Оксана Л., 5,1 років), «Тут я маленький, граю з котиком, а зараз люблю грати на планшеті» (Коля Т., 5,4 років). Але у більшості дітей (58\%) відповіді мають стислий характер («я маленький». «Сміюся»).

у старших дошкільників із системними порушеннями мовлення розповіді про себе маленького майже відсутні, більша половина дітей не брала участь у виконанні цього завдання, інші обмежувалися стислими відповідями, виходячи з чого ми дійшли попереднього висновку, що системні порушення мовлення суттєво гальмують розвиток «індивідуального Я» дитини.

Елементарні уявлення про майбутнє проявляються у дітей із системними порушеннями мовлення достатньо рано (діти знають, що виростуть, стануть дорослими), але спонтанно, під час ігрових вправ ці уявлення не актуалізуються та дослідити їх індивідуальний зміст у кожної дитини складно, оскільки у разі прямих питань («Ти будеш дорослим?») діти погоджуються із психологом. Лише одна дитина старшого дошкільного віку самостійно сказала, що хоче до школи.

Ця робота 3 активізації темпорального складника самосвідомості $€$, на наш погляд, дуже важливою, оскільки суголосно уявленням більшості дитячих психологів уявлення дітей дошкільного віку про своє майбутнє необхідно розглядати як мотивуючі, а дефіцит таких уяв- 
лень базується на недостатній диференціації елементів самосвідомості.

Як показав аналіз наукових першоджерел, удошкільному віці дитина активно прагне стати дорослою, якнайшвидше вирости [7; 8]. Ця вікова особливість може активно проявлятися у змістах сюжетно-рольових ігор дошкільнят, у бажанні стати школярем та навіть у психологічних проявах передшкільної кризи. Типовою ознакою входження у цю вікову кризу є те, що дитина починає певною мірою ігнорувати вимоги дорослих і хитрувати. Вона активно використовує для цієї мети навички сформованого позаситуативно-особистісного спілкування, вважаючи, що вже цілком компетентна у більшості питань та їй необхідно лише трохи підрости, щоб зрівнятися в правах з більш старшими дітьми або з дорослими [6]. Тому старші дошкільнята вибирають як ідеальне «Я» картинку із зображенням більш старшої людини.

Відповідно до цієї вікової особливості в нашому дослідженні діти старшого дошкільного віку з типовим розвитком мовлення обирали картинку або з зображенням дитини, старшої за віком, або дорослої людини в $(77,83 \%$ випадків). Жодна дитина не продемонструвала бажання знову стати маленькою.

В групі дітей старшого дошкільного віку із системними порушеннями мовлення, як бажану картинку з зображенням людини, старшої за віком, обирали 44\% дітей. Майже така ж кількість дітей була задоволена своїм віком. Деякі діти хотіли стати знову маленькими (15\%).

Відмінності між групами були достовірні на рівні $p<0,01$.

Важливим складником нашого дослідження була робота з батьками, які в обох групах зосереджують виховну увагу на загальному, інтелектуальному, мовленнєвому розвитку дітей, але, як було виявлено на попередній зустрічі з батьками на батьківських зборах, залишають поза увагою трансляцію дитини такої важливої культурної та психологічної норми, яка стосується фіксації уваги дитини на виділенні унікального та неповторного в її особистості та в тому числі у зовнішньому вигляді.

У таблиці 2 наведені узагальнені характеристики рівня розвитку елементів самосвідомості дітей із системними порушеннями мовлення, які залежать від стилю сімейного виховання. Нами був підрахований середній показник рівня сформованості основних елементів самосвідомості в групах, які розрізняються за стилями сімейного виховання.

Отримані результати кореспондують із науковими першоджерелами та виявилися між собою майже ідентичні, однак виявилася тенденція збільшення показника рівня самосвідомості у дітей з родин, в яких домінує приймаючий стиль виховання $(3,68 \pm 0,04)$. Найбільш несприятливим для формування елементів самосвідомості дітей старшого дошкільного віку із системними порушеннями мовлення виявився попустительський стиль сімейного виховання, за якого батьки дуже рідко фіксують увагу дитини на її зовнішньому вигляді та індивідуальних особливостях.

Висновки 3 проведеного дослідження. Проблеми системного порушення мовлення необхідно розглядати у контексті цілісного психомовленнєвого розвитку дитини, який нормативно має сприяти системному психічному, емоційному, когнітивному і соціальному розвитку особистості дитини дошкільного віку. Чим раніше будуть виявлені системні порушення мовлення і чим точніше визначені причини їх виникнення, тим більш сприятливими будуть перспективи особистісного становлення, тим вірогідніше позитивне ставлення дитини до себе та оточуючих. У дітей з системними порушеннями мовлення цей процес може бути сповільненим та своєрідним, тому необхідно своєчасно звертати дослідницьку увагу на створення умов щодо сприяння розвитку їхньої самосвідомості.

Нечисленні дослідження психомовленнєвого розвитку дітей дошкільного віку присвячені вивченню їх індивідуальності, можливих ризиків емоційної децентрації, комунікативного компоненту самосвідомості дітей із загальним недорозвиненням мовлення та вивченню комунікативної діяльності старших дошкільників із системними порушеннями мовлення з позицій особистісно-орієнтованого, діяльнісного та системного теоретико-методологічних підходів.

Проведене дослідження присвячене особливостям становлення елементів самосвідомості дітей старшого дошкільного

Таблиця 2

Залежність рівня розвитку самосвідомості дітей старшого дошкільного віку із системними порушеннями мовлення від стилю сімейного виховання

\begin{tabular}{|l|c|c|c|c|}
\hline Стиль виховання & Надвимогливий & $\begin{array}{c}\text { Протирічний } \\
\text { (непослідовний) }\end{array}$ & Попустительський & Приймаючий \\
\hline $\begin{array}{l}\text { Рівень } \\
\text { самосвідомості } \\
\text { дітей }\end{array}$ & $3,34 \pm 0,03$ & $3,24 \pm 0,01$ & $2,92 \pm 0,01$ & $3,68 \pm 0,04$ \\
\hline
\end{tabular}


віку із системними порушеннями мовлення у порівнянні із їх однолітками з типовим розвитком мовлення. Виявлено, що розвиток уявлення про себе та усний звіт про виконання завдань констатувального експерименту суттєво впливають на елементи когнітивного та мовленнєвого розвитку. Загальна тенденція до повільного темпу становлення самосприйняття є стійкою, причому це стосується як когнітивного, так і емоційного компонентів «Я-образу» дітей. Констатовано, що можливість дитини усвідомлювати себе у часовій перспективі, розділяти аспекти психологічного минулого та майбутнього не тільки є важливим елементом формування самосвідомості, але й додатковим елементом мовленнєвого розвитку. В групі дітей із системними порушеннями мовлення темпоральний складник сформований недостатньо, низка дітей бажає залишатися маленькими або бути ще меншими за віком.

Особливу роль у процесі формування основних елементів самосвідомості дітей із системними порушеннями мовлення відіграє родина, зокрема стиль сімейного виховання. Найбільш небажаним у цьому контексті є попустительський. А прийняття батьками своєї дитини позитивно впливає на самосприйняття дитини.

Перспективи подальших наукових розвідок полягають у поглибленому вивченні впливу стилів сімейного виховання на позитивні динаміки мовленнєвого розвитку дитини.

\section{ЛІТЕРАТУРА:}

1. Альбуханова-Славская К.А. Активность и сознание личности как субъекта деятельности. Активность и развитие личности. Москва, 1989. C. $110-134$.
2. Бреслав Г.М. Эмоциональные особенности формирования личности в детстве: Норма и отклонения. Київ, 2013. 144 с.

3. Василюк Ф.Е. Психология переживания. Київ, 2014. 196 C.

4. Головаха Е.И. Жизненная перспектива и ценностные ориентации личности. Психология личности в трудах отечественных психологов. Санкт-Петербург, 2014. С. 256-269.

5. Киреева 3.А. Развитие сознания, детерминированное временем : монография. Одесса, 2010. $380 \mathrm{c}$.

6. Крутій К.Л. Діагностика мовленнєвого розвитку дітей дошкільного віку. Запоріжжя, 2005. C. 78-107.

7. Кузьменко В.У. Розвиток індивідуальності дитини 3-7 років Київ, НПУ ім. М.П. Драгоманова, 2015. 365 c.

8. Мартиненко І.В. Психологічні засади фрормування комунікативної діяльності дітей старшого дошкільного віку з системними порушеннями мовлення: дис. на здобуття...доктора психологічних наук: спец.19.00.08 «Спеціальна психологія»; Національний педагогічний університет імені М.П. Драгованова. Київ, 2017. 502 с.

9. Могильова Н.М. Організаційне забезпечення дослідження комунікативного розвитку першокласників із загальним недорозвиненням мовлення. Вісник Харківського національного педагогічного університету імені Г.С. Сковороди. Серія «Психологія». Вип. 45. Ч. 1, 2013. C. $175-183$.

10. Baltaxe C. \& Simmons J. Communication deficits in preschool children with psychiatric disorders. Seminars in speech and Language, 1988. V. 8. P. 81-90.

11. Beitchman J., Hood J., Inglis A. Psychiatric risk in children with speech and language disorder. J. of Abnormal Child Psychology, 1990. V. 18. P. 282-296.

12. Tarkowski Z. Semantic Development of the Utterance of the Stutterers at the Preschool Age. J. of fluency Disorders. 1994. V. 19. N. 3. 